\title{
Misır:Arpaya Dayalı Rasyonlara Enzim İlavesinin Yumurtlayan Bıldırcınlarda Performans, Yumurta Kalitesi, Serum ve Kemik Mineral İçeriğine Etkisi*
}

\author{
Effect of Enzyme Supplementation of Maize:Barley Based Diets on the Performance, Egg \\ Quality, Serum and Bone Mineral Contents in Laying Quails
}

\section{Hatice Nur KILIÇ ${ }^{1}$} Osman OLGUN ${ }^{2 * *}$

1,2 Selçuk Üniversitesi, Ziraat Fakültesi, Zootekni Bölümü, 42130, Konya

**Sorumlu yazar: oolgun@selcuk.edu.tr

0000-0001-9131-4010

0000-0002-3732-1137
*Bu makale Hatice Nur KILIÇ'ın Yüksek Lisans tezinden özetlenmiş ve Selçuk Üniversitesi (BAP Koordinatörlüğü) tarafindan 19201110 proje numarası ile tez projesi olarak desteklenmiştir

Gönderilme Tarihi:

19 Ağustos 2020

Kabul Tarihi

\section{ÖZET}

$\mathrm{Bu}$ çalışma mısır yerine arpa kullanılan rasyonlara enzim ilavesinin yumurtlayan bildırcinlarda performans, yumurta kalitesi ile serum ve kemik mineral seviyesi üzerine etkisini belirlemek için yürütülmüştür. Dört x 2 faktöriyel deneme planında, misır yerine dört arpa seviyesinin $(\% 0$, 25,50 ve 100) ve iki enzim seviyesinin ( 0 ve $1.0 \mathrm{~g} / \mathrm{kg}$ ) oluşturulduğu 8 muamele, her birinde 5 dişi bıldırcın bulunan 4 tekerrürlü olarak denenmiştir. On haftalık yaşta toplam 160 adet dişi bildırcon 12 hafta boyunca deneme rasyonları ile yemlenmişlerdir.

Ana faktör olarak rasyon arpa seviyesi yumurtlayan bıldırcınlarda canlı ağırlık değişimini, yumurta verimini, yumurta ağırlığını, yumurta kitlesini, yem tüketimini, yemden yararlanma oranını, kabuk kırılma direncini, kabuk oran1, Haugh birimini, serum fosfor ve çinko seviyelerini ile kemik kalsiyum, manganez ve çinko seviyelerini etkilememiştir $(\mathrm{P}>0.05)$. Bıldırcın rasyonlarında mısır yerine arpa kullanımı yumurta kabuk kalınlığını $(\mathrm{P}<0.05)$ ve sarı rengini $(\mathrm{P}<0.01)$ olumsuz etkilemiştir. Serum kalsiyum $(\mathrm{P}<0.05)$, magnezyum $(\mathrm{P}<0.05)$ seviyeleri ile kemik fosfor $(\mathrm{P}<0.05)$ ve magnezyum $(\mathrm{P}<0.01)$ 
seviyeleri rasyonda arpa kullanımı ile artmıştır. Bıldırcın rasyonlarına enzim ilavesi canlı ağırlık değişimini $(\mathrm{P}<0.05)$, kabuk kırılma direncini $(\mathrm{P}<0.05)$ ve kabuk oranını $(\mathrm{P}<0.01)$ pozitif, sarı rengini ise negatif etkilemiştir $(\mathrm{P}<0.01)$. Misır:arpa ve enzim arasindaki interaksiyonlar sadece yumurta kitlesini $(\mathrm{P}<0.05)$ ve sarı rengini $(\mathrm{P}<0.01)$ önemli derecede etkilemiştir.

Sonuç olarak, sarı rengindeki olumsuz etkisi tolere edilebilir ise yumurtlayan bildircin rasyonlarında misırın yerine arpa (enzim ilaveli) kullanılabileceği söylenebilir.

Anahtar Kelimeler: Arpa, Bildırcın, Enzim, Mineral, Performans, Yumurta kalitesi

\section{ABSTRACT}

This study was carried out to determine the effect the addition of enzyme in the diets using barley instead of corn on performance, egg quality and serum and bone mineral levels in layer quails. Eight treatments consisting of four levels of barley instead of corn $(0,25,50$ and $100 \%)$ and two levels enzyme ( 0 and $1.0 \mathrm{~g} / \mathrm{kg})$ in $4 \times 2$ factorial arrangement were used with four replicates of five female birds each. A total of 160 female quails at ten weeks of age were fed with experimental diets for 12 weeks.

The dietary barley levels as a main factor did not affect body weight change, egg production, egg weight, egg mass, feed intake, feed conversion ratio, eggshell breaking strength, eggshell rate, Haugh unite, serum phosphorus and zinc levels and bone calcium, manganese and zinc levels in layer quails $(\mathrm{P}>0.05)$. The use of barley instead of corn in the quail diets negatively affected the eggshell thickness $(\mathrm{P}<0.05)$ and yolk colour $(\mathrm{P}<0.01)$. Serum calcium $(\mathrm{P}<0.05)$ and magnesium $(\mathrm{P}<0.05)$ levels and bone phosphorus $(\mathrm{P}<0.05)$ and magnesium $(\mathrm{P}<0.01)$ levels increased with the use of barley in the diet. The addition of enzyme to quail diets positively affected body weight change $(\mathrm{P}<0.05)$, eggshell breaking strength $(\mathrm{P}<0.05)$ and eggshell rate $(\mathrm{P}<0.01)$, but negatively affected yolk colour $(\mathrm{P}<0.01)$. The interactions between corn:barley and enzyme only significantly affected egg mass $(\mathrm{P}<0.05)$ and yellow colour $(\mathrm{P}<0.01)$.

As a result, it can be said that barley (enzyme added) can be used instead of corn in layer quail diets if its negative effect on yolk colour is tolerable.

Keywords: Barley, Quail, Enzyme, Performance, Egg quality, Mineral

\section{GÍRİŞ}

Kanatlı hayvanların beslenmesinde geleneksel enerji kaynağı olarak mısır kullanılmaktadır. Ülkemizde kanatlı rasyonlarında kullanılan misırın üretimi yetersiz olup, genellikle ithal olarak temin edilmektedir. Dolayısıyla ülkemizde üretimi uygun ve nispeten fiyatı daha ucuz olan arpa gibi yem hammaddelerinin kullanımının artırılması hayvansal üretimde $\% 75$ 'lere kadar varan yem maliyetinin düşürülmesi açısından önem arz etmektedir.

Arpanın mısıra göre ülkemizde üretiminin yaygın ve ucuz olmasına rağmen düşük enerji 
ve yüksek selüloz içermesi ve bunlara ilaveten içerdiği $\beta$-glukan, ksilan gibi antinutrisyonel faktörlerden dolayı kanatlı rasyonlarında kullanımı sınırlıdır. Arpa başta $\beta$-glukan olmak üzere arabinoksilanlar, fitik asit ve selüloz içermekte olup, kanatlı hayvanlarda bu bileşenleri parçalayacak enzimler bulunmamaktadır (Jeroch ve Danicke, 1995; Svihus vd., 2005). Kanatl hayvanların sindirim sisteminin kısa olması ve nişasta olmayan polisakkaritleri (NOP) hidrolize eden enzimlerin olmaması nedeniyle kanatlı hayvanlar tükettikleri tahılların sindirimini tam olarak gerçekleştiremezler, dolayısıyla yemden yeterince yararlanmaları mümkün olmamaktadır (Svihus vd., 2005).

Arpa gibi tahılların kullanıldığı kanatlı rasyonlarında ekzojen enzimlerin kullanılması yemlerin sindirimini artıracağından büyümeyi ve verimliliği artırmaktadır (Bedford ve Classen, 1992). Maliyeti yüksek olan misır yerine tritikale, buğday, arpa veya sorgum gibi düşük maliyetli ürünlerle değiştirilmesi son yıllarda tercih edilmeye başlamıştır. $\mathrm{Bu}$ ürünler NOP bakımından zengin olmakla birlikte NOP'un yemdeki içeriği ile besin değeri arasında ters bir ilişki bulunmaktadır. Kanatlılarda NOP'un sindirim organlarında enzimatik olarak parçalanabilmesi için karma yemlere $\beta$-glukanaz, ksilanaz, selülaz, pentosanaz ve ayrıca fitaz enzimleri ilave edilebilmektedir. Ekzojen enzimlerin takviyesi ile NOP'u parçalanarak yemin besin değeri artırılabilmektedir (Hetland vd., 2004). Enzimlerin kullanımı yalnızca besleme ve ekonomik açıdan değil sağlık ve çevre açısından da önemlidir. Enzimler organik maddelerin sindirimini ve inorganik maddelerin kullanımını geliştirdiğinden, dışkı miktarı azalmakta ve bunun sonucu besin madde atılımı özellikle azot, fosfor ve çinko atılımı azaltmaktadır (Alagawany vd., 2018).

Üreticinin yem maliyetini en aza indirmek için bölgesinde yetiştirilen arpa gibi tahıllar yani enerji ek yemleri tercih edilebilmektedir. Ayrıca arpa ülkemizin her bölgesinde yetiştirilebilirken, mısır bol suya ihtiyaç duyduğu için ekim alanı sinırlı olmakta bu sinırlamadan dolayı arpanın hayvan beslemede özellikle kanatlı beslemesinde kullanımı tavsiye edilmektedir (Mohammed vd., 2010). Arpanın kanatlı hayvanlarda olumsuz etkisinin azaltılması, sindirebilirliğinin artması ve dolayısıyla kanatlı rasyonlarında kullanım seviyesinin arttırılmasında $\beta$-glukanaz, ksilanaz, selülaz ve fitaz gibi enzim preparatlarının kullanımı katkı sağlayacaktır.

$\mathrm{Bu}$ çalışmanın amacı yumurtlayan bıldırcın rasyonlarında tahıl kaynağı olarak mısır yerine enzimsiz veya enzimli arpa kullanımının başta performans ve kabuk kalitesi olmak üzere kemik ve serum mineralleri üzerine etkisini belirlemektir.

\section{MATERYAL VE YÖNTEM}

Bu çalışma Eylül-Aralık 2019 tarih aralığında gerçekleştirilmiş olup, çalışmanın yürütülmesi ve sonuçların yazılması esnasında Araştırma ve Yayın Etiğine uyulmuştur.

Çalışmada 10 haftalık yaşta 160 adet yumurtlayan bıldırcın kullanılmıştır. Çalışma Selçuk Üniversitesi Ziraat Fakültesine ait Zootekni Bölümü Prof. Dr. Orhan Düzgüneş Hayvancılık 
Çizelge 1. Deneme rasyonları ve hesaplanmış besin madde içerikleri

\begin{tabular}{|l|c|c|c|c|}
\hline \multirow{2}{*}{ Hammaddeler, \% } & \multicolumn{3}{|c|}{ Misır:Arpa } & $\mathbf{0 : 1 0 0}$ \\
\cline { 2 - 5 } & $\mathbf{1 0 0 : 0}$ & $\mathbf{7 5 : 2 5}$ & $\mathbf{5 0 : 5 0}$ & 0.00 \\
\hline Misır & 58.00 & 43.50 & 29.00 & 58.00 \\
\hline Srpa & 0.00 & 14.50 & 29.00 & 27.13 \\
\hline Bitkisel yağ & 31.50 & 30.37 & 29.34 & 7.40 \\
\hline Mermer tozu & 2.95 & 4.10 & 5.17 & 5.62 \\
\hline Dikalsiyum fosfat & 5.60 & 5.60 & 5.60 & 1.07 \\
\hline Tuz & 1.18 & 1.15 & 1.12 & 0.35 \\
\hline Premiks1 & 0.35 & 0.35 & 0.35 & 0.25 \\
\hline DL-metiyonin & 0.25 & 0.25 & 0.25 & 0.18 \\
\hline Hesaplanmiş besin maddeleri & 0.17 & 0.18 & 0.17 & \\
\hline Metabolik enerji, kkal/kg & & & & 2889 \\
\hline Ham protein, \% & 2901 & 2901 & 2895 & 19.89 \\
\hline Lisin, \% & 20.03 & 19.93 & 20.05 & 1.02 \\
\hline Metiyonin, \% & 1.05 & 1.05 & 1.04 & 0.45 \\
\hline Metiyonin + sistin, \% & 0.45 & 0.45 & 0.44 & 0.83 \\
\hline Kalsiyum, \% & 0.82 & 0.83 & 0.82 & 2.49 \\
\hline Kullan1labilir fosfor, \% & 2.50 & 2.50 & 2.49 & 0.35 \\
\hline Vinin-Mingesi & 0.35 & 0.35 & 0.35 & 0.15 \\
\hline
\end{tabular}

${ }^{1}$ Vitamin-Mineral premiksi rasyonun 1 kg'ında; manganez: $80 \mathrm{mg}$; demir: $60 \mathrm{mg}$; bakır: $5 \mathrm{mg}$; iyot, $1 \mathrm{mg}$; selenyum: 0.15 $\mathrm{mg}$, vitamin A, $8.800 \mathrm{IU}$; vitamin $\mathrm{D}_{3}, 2.200 \mathrm{IU}$; vitamin E, $11 \mathrm{mg}$; nikotin asit, $44 \mathrm{mg}$; Cal-D-Pan, $8.8 \mathrm{mg}$; riboflavin $4.4 \mathrm{mg}$; tiamin $2.5 \mathrm{mg}$; vitamin $\mathrm{B}_{12}, 6.6 \mathrm{mg}$; folik asit, $1 \mathrm{mg}$; biyotin, $0.11 \mathrm{mg}$; kolin: $220 \mathrm{mg}$ sağlar.

Araştırma ve Uygulama Tesisleri Bıldırcın kümesinde gerçekleştirilmiştir. Çalışmada kullanılan bildırcın, yem hammaddeleri, vitamin-mineral premiksi ve enzim preparatı (fitaz, ksilanaz, glukanaz, mannaz, proteaz, alfa amilaz, lipaz ve pektinaz) ticari firmalardan temin edilmiştir. Denemede kullanılan rasyonların içeriği ve besin madde kompozisyonları Çizelge 1.'de verilmiştir.

\section{Yöntem}

Denemede misir yerine arpanin $4(\% 0,25,50$ ve 100) ve enzimin (fitaz, ksilanaz, glukanaz, mannaz, proteaz, alfa amilaz, lipaz ve pektinaz) 2 seviyesinden $(0$ ve $1 \mathrm{~g} / \mathrm{kg}$ ) oluşan toplam 8 rasyon hazırlanmıştır. Çalışma her birinde 5 dişi bıldırcının bulunduğu her biri 4 tekerrürden oluşan 8 muamele grubundan oluşturulmuştur. Denemede misir:arpa oranı ve enzim ilavesinin oluşturduğu gruplar; 1. grup kontrol (100:0 enzimsiz), 2. grup (100:0 enzimli), 3. grup (75:25 enzimsiz), 4. grup (75:25 enzimli), 5. grup (50:50 enzimsiz), 6. grup (50:50 enzimli), 7. grup (0:100 enzimsiz) ve 8 . grup $(0: 100$ enzimli) olarak düzenlenmiştir. Denemede NRC (1994) tarafından bıldırcınlar için tavsiye edilen seviyelerde besin maddesi içeren deneme rasyonları hazırlanmıştır (Çizelge 1). Deneme rasyonları yumurtlayan bildircinlara 12 hafta boyunca verilmiştir. Hayvanlara su ve yem 
hayvanlara serbest olarak sunulmuş ve günde 16 saat aydınlatma uygulanmıştır.

\section{Performans parametrelerinin tespiti}

Deneme başlangıcında ve sonunda her alt gruptaki hayvanlar grup olarak tartılıp, deneme başlangıcı ve sonu canlı ağırlıkları tespit edilmiş ve bu verilerden canlı ağırlık değişimleri hesaplanmıştır. Bıldırcınların verdiği yumurtalar günlük olarak sayılmış ve yüzdesi alınarak grupların \% yumurta verimleri tespit edilmiştir. Denemenin her 4 haftalı periyodunun son iki günü her alt gruptaki toplanan bütün yumurtalar beraber tartılmış ve ortalaması alınarak ortalama yumurta ağırlığı g olarak tespit edilmiştir. Bıldırcın başına ortalama \% yumurta veriminin yumurta ağırlığı ile çarpılıp 100'e bölünmesi [yumurta kitlesi $=(\%$ yumurta verimi x yumurta ağırlığı) /100] ile grupların yumurta kitlesi g/gün/ bıldırcın olarak hesaplanmıştır. Yemler gruplara (kafes gözlerine) tartılarak verilmiş olup, her 4 haftalık periyot sonunda yemlikte tüketilmeyen yemler tartılmış ve deneme sonunda ortalamaları alınarak yem tüketimi g/gün/bıldırcın olarak tespit edilmiştir. Yem tüketiminin (g/gün/ bıldırcın) yumurta kitlesine (g/gün/bıldırcın) bölünmesi ile grupların yemden yararlanma oranı bulunmuştur (Olgun ve Yıldız, 2017).

\section{Yumurta kalite parametrelerinin tespiti}

Yumurta diş kalite parametreleri (kabuk kırılma direnci, kabuk oranı ve kabuk kalınlığı) denemenin her 4 haftalik periyodunun son iki günde toplanan tüm yumurtalarda tespit edilmiştir. Yumurta kabuğu kırılma direnci 0-5000 g ölçüm aralığında yumurta kırılma direnci ölçme cihazı (Orka Food Teknolojisi,
İsrail) ile $\mathrm{kg}$ olarak belirlenmiștir. Yumurta kabuk oranları ise, yumurtaların içi boşaltılmış, musluk suyunda yıkanmış ve $105{ }^{\circ} \mathrm{C}$ 'de bir gün etüvde kurutulup, oda sicaklığında bekletilerek soğutulmuş 0.01 g'a hassas teraziyle tartılmış ve ortalama yumurta ağırlığına bölünüp yüz ile çarpılmasıyla \% kabuk oranları hesaplanmıştır. Kırılma gücü tespit edilen yumurtalarda kumpas yardımı ile küt ve sivri taraflarından bir, orta kısmından iki ölçüm alınarak $\mu \mathrm{m}$ olarak yumurta kabuk kalınlığı tespit edilmiştir (Olgun ve Yıldız, 2017).

Kabuk kırılma direnci ölçülen yumurtalar yumurta akının ve sarısının yapısı bozulmayacak şekilde cam bir masaya kırılmış, yumurta akı yüksekliği dijital yükseklik mihengiri tespit edilmiş ve 100 x log (ak yüksekliği + 7.571.7 x yumurta ağırlığ ${ }^{0.37}$ ) formüllü yardımıyla Haugh birimi bulunmuştur. Yumurta sarısı rengi ise Roch renk skalası ile karşılaştırma yaparak en yakın renge göre numaralandırılmış, bu numaralandırma en açık renk 1 en koyu renk 15 olarak numaralandırılmıştır. Yumurta iç ve dış kalite parametrelerinin hepsi aynı günde toplanan yumurtalarda bir günde tamamlanmıştır.

\section{Mineral analizleri}

Deneme sonunda serum ve kemik mineral içeriğini belirlemek amaciyla her alt gruptan rastgele 1 adet bıldırcın kesilerek kan alınmış ve bu hayvanlar kesilip tibiaları alınmıştır. Tibiaların (kemiklerin) mineral element muhtevaları için alınan sağ tibialar plastik torbalarda analize kadar $-20{ }^{\circ} \mathrm{C}$ 'de dondurucuda muhafaza edilmiştir. Analizden 24 saat önce derin dondurucudan kemikler çıkartılmış ve çözülmeleri için oda 
Sıcaklığında bekletilmiştir. Kemikler etüvde 105 ${ }^{\circ} \mathrm{C} 24$ saat kurutulmaya bırakılmış ve 24 saatin sonunda mineral analizleri kuru madde üzerinden yapılmıştır. Serum (kalsiyum, magnezyum, fosfor ve çinko) ve kemik mineral (kalsiyum, magnezyum, fosfor, çinko ve manganez) içeriklerini belirlemek için serumdan 1-1.50 g ve kemikten 0.3-0.5 g alınan örneklere iki cc hidrojen peroksit ve beş cc nitrik asit eklenerek mikrodalga cihazında (MarsXpress Techonology Inside) 40 dakika süreyle $190{ }^{\circ} \mathrm{C}$ 'de ve 175 PSI'de yakılmıştır. Daha sonra ultra saf su ile serumlar 10 cc'ye kemik örnekleri 50 cc'ye tamamlanarak ICP-AES cihazında mineral içerikleri belirlenmiştir (Skujins, 1998).

\section{İstatistikî analiz}

Araştırmada, 4 farklı arpa (\%0, 25, 50 ve 100) ve 2 farklı enzim ( 0 ve $1 \mathrm{~g} / \mathrm{kg}$ ) ilavesinin oluşturduğu 8 muamele grubu tesadüf parsellerinde, $4 \times 2$ faktöriyel deneme planına göre ve 4 tekerrürlü olarak denendiğinden, deneme sonuçları faktöriyel deneme planına göre analiz edilmiştir. Muamele gruplarının incelenen özellikleri önemli olarak etkileyip etkilemedikleri bir istatistik programı yardımıyla (Minitab, 2000) belirlenmiş ve muamele gruplarının etkisinin önemli bulunduğu durumlarda Duncan Testi ile farklılıklar belirlenmiştir (Duncan, 1955).

\section{BULGULAR VE TARTIŞMA \\ Performans}

Yumurtlayan bildırcin rasyonlarında misır yerine arpa kullanımı ve enzim ilavesinin performans üzerine etkisi Çizelge 2'de verilmiştir.

Rasyonda mısır yerine arpa kullanımının canlı ağırlık değişimi, yem tüketimi, yumurta verimi, ağırlığı ve kitlesi ile yemden yararlanma oranına etkisi önemsiz bulunmuştur $(\mathrm{P}>0.05) . \quad \mathrm{Bu}$ sonuçlar Jamroz vd. (2001), Lazaro vd. (2003) ile Herbert vd. (2011) ile benzerlik göstermektedir. $\mathrm{Bu}$ durum performans açısından arpanın misır yerine kullanılmasının mümkün olduğunu göstermesi bakımından önem arz etmektedir.

Yumurtlayan bildircin rasyonlarına enzim ilavesi ile canlı ağırlık artışı önemli derecede yüksek olurken $(\mathrm{P}<0.05)$, diğer performans parametrelerini etkilememiştir $\quad(\mathrm{P}>0.05)$. Mathlouthi vd. (2003) \%20 arpa ve \%50 buğday içeren yumurta tavuk rasyonlarına enzim ilavesi ile canlı ağırlığın arttığını bildirmişlerdir. Ancak Hamilton ve Proudfoot (1993), Jamroz vd. (2001), Lazaro vd. (2003) ile Yörük ve Bolat (2003) yumurta tavuklarında (\%15 ila 60) arpa içeren rasyonlara enzim ilavesi ile canlı ağırlığın değişmediğini bildirmişlerdir.

Rasyon misır:arpa seviyesi ve enzim ilavesinin oluşturduğu interaksiyonlar yumurta kitlesini önemli derecede etkilerken $(\mathrm{P}<0.05)$, diğer performans parametrelerine etkisi olmamıştır $(\mathrm{P}>0.05)$. En yüksek yumurta kitlesi 50:50 x 1.0 grubunda elde edilmiş olup, bu grup ile sadece 75:25 x 0.0 grubu arasındaki farklılık istatistiki olarak önemli bulunmuştur. Jamroz vd. (2001), Lazaro vd. (2003), Mathlouthi vd. (2003) ile Mohammed vd. (2010) yumurta tavuklarında arpa ile enzim interaksiyonlarının yumurta kitlesine etkisinin olmadığını bildirmişlerdir.

\section{Yumurta kalitesi}

Yumurtlayan bildircin rasyonlarinda misir 
Çizelge 2. Rasyon mısır:arpa ve enzim seviyelerinin yumurtlayan bıldırcınlarda performansa etkisi.

\begin{tabular}{|c|c|c|c|c|c|c|}
\hline Muameleler & $\begin{array}{c}\text { Canlı } \\
\text { ağırlık } \\
\text { değişimi, } g\end{array}$ & $\begin{array}{c}\text { Yumurta } \\
\text { verimi, \% }\end{array}$ & $\begin{array}{l}\text { Yumurta } \\
\text { ağırlığı, } g\end{array}$ & $\begin{array}{c}\text { Yumurta } \\
\text { kitlesi, g/gün/ } \\
\text { bıldırcın }\end{array}$ & $\begin{array}{l}\text { Yem tüketimi, } \\
\text { g/gün/bıldırcın }\end{array}$ & $\begin{array}{c}\text { Yemden } \\
\text { yararlanma } \\
\text { oranı }\end{array}$ \\
\hline \multicolumn{7}{|l|}{ Misır:Arpa } \\
\hline 100:0 & $15.33 \pm 3.50$ & $92.27 \pm 0.77$ & $12.39 \pm 0.18$ & $11.43 \pm 0.21$ & $31.44 \pm 0.66$ & $2.76 \pm 0.07$ \\
\hline $75: 25$ & $12.16 \pm 4.03$ & $87.84 \pm 1.74$ & $12.78 \pm 0.18$ & $11.23 \pm 0.27$ & $31.96 \pm 0.46$ & $2.86 \pm 0.06$ \\
\hline $50: 50$ & $9.71 \pm 5.49$ & $91.03 \pm 2.07$ & $12.70 \pm 0.18$ & $11.56 \pm 0.31$ & $31.71 \pm 0.58$ & $2.75 \pm 0.07$ \\
\hline $0: 100$ & $21.20 \pm 2.02$ & $91.42 \pm 1.20$ & $12.92 \pm 0.09$ & $11.81 \pm 0.08$ & $31.24 \pm 0.28$ & $2.65 \pm .04$ \\
\hline $\mathrm{P}$ değeri & 0.201 & 0.166 & 0.119 & 0.273 & 0.738 & 0.156 \\
\hline \multicolumn{7}{|l|}{ Enzim, $\mathrm{g} / \mathrm{kg}$} \\
\hline 0.0 & $10.49 \pm 3.01^{b}$ & $89.53 \pm 1.19$ & $12.70 \pm 0.13$ & $11.37 \pm 0.06$ & $30.77 \pm 0.35$ & $2.77 \pm 0.05$ \\
\hline 1.0 & $18.71 \pm 2.36^{\mathrm{a}}$ & $91.74 \pm 0.99$ & $12.70 \pm 0.12$ & $11.64 \pm 0.05$ & $31.71 \pm 0.36$ & $2.74 \pm 0.03$ \\
\hline $\mathrm{P}$ değeri & 0.043 & 0.135 & 0.609 & 0.198 & 0.383 & 0.587 \\
\hline \multicolumn{7}{|c|}{ Misir:Arpa x Enzim } \\
\hline $100: 0 \times 0.0$ & $10.99 \pm 3.70$ & $93.71 \pm 0.47$ & $12.65 \pm 0.32$ & $11.85 \pm 0.11^{\mathrm{a}}$ & $32.26 \pm 0.75$ & $2.73 \pm 0.09$ \\
\hline $100: 0 \times 1.0$ & $19.68 \pm 5.57$ & $90.84 \pm 1.08$ & $12.13 \pm 0.08$ & $11.01 \pm 0.06^{\mathrm{ab}}$ & $30.62 \pm 1.01$ & $2.78 \pm 0.11$ \\
\hline $75: 25 \times 0.0$ & $8.55 \pm 7.43$ & $86.36 \pm 1.69$ & $12.46 \pm 0.24$ & $10.74 \pm 0.10^{\mathrm{b}}$ & $31.64 \pm 0.50$ & $2.95 \pm 0.06$ \\
\hline $75: 25 \times 1.0$ & $15.76 \pm 3.44$ & $89.32 \pm 3.03$ & $13.11 \pm 0.16$ & $11.71 \pm 0.42^{\mathrm{a}}$ & $32.29 \pm 0.81$ & $2.77 \pm 0.09$ \\
\hline $50: 50 \times 0.0$ & $3.33 \pm 7.78$ & $87.72 \pm 3.40$ & $12.74 \pm 0.33$ & $11.18 \pm 0.51^{\mathrm{ab}}$ & $30.82 \pm 0.98$ & $2.77 \pm 0.14$ \\
\hline $50: 50 \times 1.0$ & $16.09 \pm 7.28$ & $94.33 \pm 1.02$ & $12.66 \pm 0.20$ & $11.95 \pm 0.29^{\mathrm{a}}$ & $32.59 \pm 0.30$ & $2.73 \pm 0.06$ \\
\hline $0: 100 \times 0.0$ & $19.10 \pm 2.99$ & $90.35 \pm 1.56$ & $12.96 \pm 0.06$ & $11.71 \pm 0.21^{\mathrm{a}}$ & $30.77 \pm 0.36$ & $2.63 \pm 0.07$ \\
\hline $0: 100 \times 1.0$ & $23.30 \pm 1.67$ & $92.48 \pm 1.87$ & $12.88 \pm 0.19$ & $11.91 \pm 0.20^{\mathrm{a}}$ & $31.71 \pm 0.30$ & $2.67 \pm 0.06$ \\
\hline P değeri & 0.886 & 0.161 & 0.618 & 0.024 & 0.108 & 0.526 \\
\hline
\end{tabular}

a, b; Aynı sütunda farklı harfler ile gösterilen ortalamalar arasındaki farklılık istatistiki olarak önemlidir $(\mathrm{P}<0.05)$.

yerine arpa kullanımının ve enzim ilavesinin yumurta kalite parametrelerine etkisi Çizelge 3'te verilmiştir. Ana faktör olarak mısır:arpa oranının hasarlı yumurta oranını, kabuk kırılma direncini, kabuk oranını ve Haugh birimini istatistiki olarak etkilemezken $(\mathrm{P}>0.05)$, kabuk kalınlığını ve yumurta sarı rengini önemli seviyede etkilemiştir $(\mathrm{P}<0.01)$. Yumurta kabuk kalınlığı rasyonda mısır yerine arpa kullanımı ile önemli derecede azalmış ancak arpa seviyeleri arasındaki farklılık benzer olmuştur. Mohammed vd. (2010) yumurta tavuklarında $\% 45$ arpa kullanımı ile yumurta kabuk kalınlığının azaldığını ancak arpa $(\% 0,15,30$ ve 60) oranlarının etkilemediğini bildirmişlerdir. Jamroz vd. (2001) ile Perez-Bonilla vd. (2011) yumurtacı tavuk rasyonlarında arpa kullanımının (sırasıyla \%66 ve 45) kabuk kalınlığı dahil yumurta kalite parametrelerini etkilemediğini bildirmişlerdir. Yumurta sarı rengi rasyonda arpa kullanımı ile önemli derece düşmüş ve her arpa seviyesi arasındaki farklılık istatistiki olarak önemli olmuştur. Bıldırcın rasyonlarına enzim ilavesi kabuk kalınlığını, hasarlı yumurta oranını ve Haugh birimini etkilenmezken $(\mathrm{P}>0.05)$, kabuk kırılma direnci $(\mathrm{P}<0.01)$ ve kabuk oranı 
Çizelge 3. Rasyon mısır:arpa ve enzim seviyelerinin yumurtlayan bıldırcınlarda yumurta kalitesine etkisi.

\begin{tabular}{|c|c|c|c|c|c|c|}
\hline Muameleler & $\begin{array}{c}\text { Hasarlı } \\
\text { yumurta } \\
\text { oranı, \% }\end{array}$ & $\begin{array}{c}\text { Kabuk } \\
\text { kırılma } \\
\text { direnci, kg }\end{array}$ & $\begin{array}{c}\text { Kabuk } \\
\text { oranı, \%1 }\end{array}$ & $\begin{array}{c}\text { Kabuk } \\
\text { kalınlığı, } \\
\mu \mathrm{m}\end{array}$ & $\begin{array}{l}\text { Haugh } \\
\text { birimi }\end{array}$ & Sarı rengi ${ }^{2}$ \\
\hline \multicolumn{7}{|l|}{ Misir:Arpa } \\
\hline 100:0 & $0.97 \pm 0.40$ & $1.59 \pm 0.02$ & $8.07 \pm 0.10$ & $248.9 \pm 4.06^{\mathrm{A}}$ & $78.42 \pm 0.45$ & $5.16 \pm 0.08^{\mathrm{A}}$ \\
\hline $75: 25$ & $3.27 \pm 1.12$ & $1.55 \pm 0.05$ & $8.03 \pm 0.14$ & $230.6 \pm 2.08^{\mathrm{B}}$ & $78.84 \pm 0.86$ & $3.61 \pm 0.43^{\mathrm{C}}$ \\
\hline $50: 50$ & $3.36 \pm 1.58$ & $1.54 \pm 0.02$ & $8.02 \pm 0.13$ & $231.1 \pm 2.40^{\mathrm{B}}$ & $77.09 \pm 0.88$ & $4.14 \pm 1.20^{\mathrm{B}}$ \\
\hline $0: 100$ & $1.05 \pm 0.53$ & $1.55 \pm 0.03$ & $7.86 \pm 0.10$ & $226.1 \pm 2.15^{\mathrm{B}}$ & $77.80 \pm 1.33$ & $2.03 \pm 0.11^{\mathrm{D}}$ \\
\hline P değeri & 0.124 & 0.673 & & 0.001 & & \\
\hline \multicolumn{7}{|l|}{ Enzim, g/kg } \\
\hline 0.0 & $2.89 \pm 0.87$ & $1.52 \pm 0.02^{\mathrm{B}}$ & $7.87 \pm 0.08^{\mathrm{b}}$ & $234.3 \pm 3.61$ & $77.98 \pm 0.72$ & $4.17 \pm 0.31^{\mathrm{A}}$ \\
\hline 1.0 & $1.44 \pm 0.57$ & $1.60 \pm 0.02^{\mathrm{A}}$ & $8.12 \pm 0.07^{\mathrm{a}}$ & $234.1 \pm 2.08$ & $78.10 \pm 0.59$ & $3.30 \pm 0.33^{\mathrm{B}}$ \\
\hline P değeri & 0.127 & 0.010 & 0.020 & 0.963 & 0.904 & 0.001 \\
\hline \multicolumn{7}{|c|}{ Misır:Arpa x Enzim } \\
\hline $100: 0 \times 0.0$ & $0.74 \pm 0.47$ & $1.59 \pm 0.03$ & $8.09 \pm 0.13$ & $254.5 \pm 5.58$ & $78.68 \pm 0.62$ & $5.26 \pm 0.15^{\mathrm{A}}$ \\
\hline $100: 0 \times 1.0$ & $1.21 \pm 0.69$ & $1.58 \pm 0.002$ & $8.05 \pm 0.17$ & $243.3 \pm 4.99$ & $78.15 \pm 0.73$ & $5.05 \pm 0.06^{\mathrm{A}}$ \\
\hline $75: 25 \times 0.0$ & $5.98 \pm 0.85$ & $1.46 \pm 0.04$ & $7.75 \pm 0.18$ & $228.5 \pm 3.38$ & $79.41 \pm 1.23$ & $4.74 \pm 0.09^{\mathrm{AB}}$ \\
\hline $75: 25 \times 1.0$ & $0.56 \pm 0.46$ & $1.65 \pm 0.05$ & $8.30 \pm 0.07$ & $232.8 \pm 2.25$ & $78.26 \pm 1.30$ & $2.48 \pm 0.10^{\mathrm{D}}$ \\
\hline $50: 50 \times 0.0$ & $4.47 \pm 2.54$ & $1.52 \pm 0.03$ & $7.78 \pm 0.15$ & $228.3 \pm 3.73$ & $75.88 \pm 1.62$ & $4.39 \pm 0.37^{\mathrm{BC}}$ \\
\hline $50: 50 \times 1.0$ & $2.25 \pm 2.08$ & $1.57 \pm 0.04$ & $8.26 \pm 0.13$ & $234.0 \pm 2.74$ & $78.30 \pm 0.18$ & $3.90 \pm 0.08^{\mathrm{C}}$ \\
\hline $0: 100 \times 0.0$ & $0.35 \pm 0.18$ & $1.52 \pm 0.04$ & $7.85 \pm 0.14$ & $225.8 \pm 4.52$ & $77.94 \pm 1.87$ & $2.29 \pm 0.04^{\mathrm{DE}}$ \\
\hline $0: 100 \times 1.0$ & $1.75 \pm 0.97$ & $1.59 \pm 0.04$ & $7.87 \pm 0.15$ & $226.5 \pm 1.04$ & $77.67 \pm 2.17$ & $1.77 \pm 0.10^{\mathrm{E}}$ \\
\hline $\mathrm{P}$ değeri & 0.061 & 0.080 & 0.102 & 0.132 & 0.583 & 0.001 \\
\hline
\end{tabular}

A,B,C,D,E; Aynı sütunda farklı harfler ile gösterilen ortalamalar arasındaki farklılık istatistiki olarak önemlidir (P<0.01). ${ }^{\text {a, b} ; ~ A y n ı ~}$ sütunda farklı harfler ile gösterilen ortalamalar arasındaki farklılık istatistiki olarak önemlidir $(\mathrm{P}<0.05)$. ${ }^{1}$ Yumurta ağırlığının $\%$ 'si. ${ }^{2}$ Roche renk skalası

$(\mathrm{P}<0.05)$ önemli derecede artmış ve aksine yumurta sarı rengi önemli derecede azalmıştır $(\mathrm{P}<0.01)$.

Perez-Bonilla vd. (2011) rasyonda \%45 arpa kullanımı ile yumurta sarı renginin azaldığını bildirmişlerdir. Benzer olarak Herbert vd. (2011) yumurta tavuk rasyonlarında \%57.7 arpa kullanımı ile yumurta sarı renginin azaldığını, ancak enzim ilavesinin etkisinin olmadığını bildirmiştir. İlaveten Jamroz vd. (2001) arpa içeren rasyonlara enzim ilavesinin yumurta sarı rengini etkilemediğini bildirmișlerdir. Mohammed vd. (2010) arpa içeren rasyonlara enzim ilavesi ile kabuk oranının etkilenmediğini, kabuk kalınlığının ise arttığını bildirmişlerdir.

Rasyonda arpa kullanımı ile kabuk kalite parametrelerinden sadece kabuk kalınlığ olumsuz etkilenirken, enzim ilavesi ile kabuk oranı ve kabuk kırılma direnci olumlu yönde etkilenmiştir. Dolayısıyla arpakullanımıilekabuk kalitesinde oluşabilecek problemlerin enzim ilavesi ile önlenebileceği söylenebilir. Ancak yumurta sarı rengi üzerine arpanın ve enzimin 
olumsuz etkisini gidermek amacıyla rasyonda mutlaka doğal renklendirici kullanımının tüketici tercihi açısından gerekli olduğu görülmektedir.

\section{Serum ve kemik mineralleri}

Yumurtalayan bildırcin rasyonlarında misır yerine arpa kullanımı ve enzim ilavesinin serum minerallerine etkisi Çizelge 4'te, kemik minerallerine etkisi ise Çizelge 5'te verilmiştir. Ana faktör olarak rasyona enzim ilavesi ve misır:arpa ile enzimin oluşturduğu interaksiyonların serum mineralleri üzerine etkisi olmamıştır $(\mathrm{P}>0.05)$. Ana faktör olarak misır:arpa oranı serum fosfor ve çinko seviyelerini etkilemezken $(\mathrm{P}>0.05)$, serum kalsiyum ve magnezyum seviyelerini önemli derecede etkilemiştir $(\mathrm{P}<0.05)$. Kontrol (100:0) grubu ile karşılaştırıldığında rasyonda arpa kullanımı ile serum kalsiyum seviyesi artmış ve bu artış 75:25 ile 50:50 gruplarında istatistiki olarak önemli olmuştur. Yine kontrol (100:0) grubu ile karşılaştırıldığında serum magnezyum seviyesi önemli derece artmıştır, ancak arpa seviyeleri arasındaki farklılık benzer olmuştur.

Çizelge 4. Rasyon mısır:arpa ve enzim seviyelerinin yumurtlayan bıldırcınlarda serum minerallerine et$\mathrm{kisi}, \mathrm{mg} / \mathrm{kg}$.

\begin{tabular}{|c|c|c|c|c|}
\hline Muameleler & Kalsiyum & Fosfor & Magnezyum & Çinko \\
\hline \multicolumn{5}{|l|}{ Misir:Arpa } \\
\hline 100:0 & $236.9 \pm 25.47^{b}$ & $440.7 \pm 45.36$ & $37.10 \pm 4.46^{\mathrm{b}}$ & $5.700 \pm 0.88$ \\
\hline $75: 25$ & $331.2 \pm 23.44^{a}$ & $609.5 \pm 32.46$ & $49.20 \pm 2.55^{\mathrm{a}}$ & $7.111 \pm 0.51$ \\
\hline $50: 50$ & $323.5 \pm 30.92^{\mathrm{a}}$ & $573.3 \pm 65.97$ & $48.60 \pm 3.17^{\mathrm{a}}$ & $6.200 \pm 0.70$ \\
\hline $0: 100$ & $299.7 \pm 15.16^{\mathrm{ab}}$ & $570.2 \pm 61.62$ & $46.65 \pm 1.87^{\mathrm{a}}$ & $6.000 \pm 0.47$ \\
\hline P değeri & 0.044 & 0.124 & 0.024 & 0.512 \\
\hline \multicolumn{5}{|l|}{ Enzim, $\mathrm{g} / \mathrm{kg}$} \\
\hline 0.0 & $318.6 \pm 17.04$ & $559.6 \pm 30.43$ & $47.65 \pm 1.86$ & $6.506 \pm 0.37$ \\
\hline 1.0 & $277.1 \pm 19.78$ & $537.2 \pm 47.23$ & $43.13 \pm 2.89$ & $6.000 \pm 0.56$ \\
\hline $\mathrm{P}$ değeri & 0.098 & 0.663 & 0.133 & 0.467 \\
\hline \multicolumn{5}{|c|}{ Misir:Arpa x Enzim } \\
\hline $100: 0 \times 0.0$ & $267.4 \pm 22.87$ & $479.3 \pm 37.00$ & $45.20 \pm 5.39$ & $6.400 \pm 0.80$ \\
\hline $100: 0 \times 1.0$ & $206.4 \pm 43.39$ & $402.2 \pm 85.10$ & $29.0 \pm 4.47$ & $5.000 \pm 1.64$ \\
\hline $75: 25 \times 0.0$ & $352.1 \pm 42.14$ & $589.7 \pm 61.65$ & $49.79 \pm 5.04$ & $7.123 \pm 1.08$ \\
\hline $75: 25 \times 1.0$ & $310.2 \pm 22.24$ & $629.4 \pm 29.10$ & $48.60 \pm 2.19$ & $7.100 \pm 0.19$ \\
\hline $50: 50 \times 0.0$ & $359.8 \pm 34.01$ & $671.7 \pm 64.80$ & $51.10 \pm 1.61$ & $6.800 \pm 0.28$ \\
\hline $50: 50 \times 1.0$ & $287.2 \pm 49.28$ & $474.9 \pm 98.20$ & $46.10 \pm 6.33$ & $5.600 \pm 1.40$ \\
\hline $0: 100 \times 0.0$ & $295.0 \pm 18.83$ & $497.8 \pm 35.30$ & $44.50 \pm 1.00$ & $5.700 \pm 0.53$ \\
\hline $0: 100 \times 1.0$ & $304.4 \pm 26.51$ & $642.5 \pm 113.95$ & $48.80 \pm 3.49$ & $6.300 \pm 0.82$ \\
\hline P değeri & 0.644 & 0.126 & 0.111 & 0.695 \\
\hline
\end{tabular}

a, b; Aynı sütunda farklı harfler ile gösterilen ortalamalar arasındaki farklılık istatistiki olarak önemsizdir $(\mathrm{P}>0.05)$ 
Çizelge 5. Rasyon mısır:arpa ve enzim seviyelerinin yumurtlayan bıldırcınlarda kemik mineral konsantrasyonlarına etkisi.

\begin{tabular}{|c|c|c|c|c|c|}
\hline Muameleler & $\begin{array}{c}\text { Kalsiyum, } \\
\text { mg/g }\end{array}$ & $\begin{array}{c}\text { Fosfor, } \\
\text { mg/g }\end{array}$ & $\begin{array}{c}\text { Magnezyum, } \\
\text { mg/g }\end{array}$ & $\begin{array}{c}\text { Manganez, } \\
\text { mg/kg }\end{array}$ & $\begin{array}{l}\text { Çinko, } \\
\text { mg/kg }\end{array}$ \\
\hline \multicolumn{6}{|l|}{ Misır:Arpa } \\
\hline $100: 0$ & $251.8 \pm 6.52$ & $104.0 \pm 3.80^{\mathrm{b}}$ & $3.305 \pm 0.16^{\mathrm{B}}$ & $15.36 \pm 0.81$ & $347.7 \pm 22.58$ \\
\hline $75: 25$ & $259.2 \pm 6.37$ & $115.4 \pm 2.79^{a}$ & $3.899 \pm 0.15^{\mathrm{A}}$ & $20.80 \pm 3.62$ & $386.0 \pm 36.76$ \\
\hline $50: 50$ & $254.0 \pm 3.44$ & $111.4 \pm 2.13^{\mathrm{ab}}$ & $3.745 \pm 0.11^{\mathrm{AB}}$ & $13.63 \pm 1.33$ & $286.1 \pm 12.99$ \\
\hline $0: 100$ & $266.7 \pm 4.95$ & $115.4 \pm 2.18^{\mathrm{a}}$ & $3.981 \pm 0.12^{\mathrm{A}}$ & $18.58 \pm 3.08$ & $319.8 \pm 27.81$ \\
\hline P değeri & 0.236 & 0.023 & 0.005 & 0.128 & 0.056 \\
\hline \multicolumn{6}{|l|}{ Enzim, g/kg } \\
\hline 0.0 & $255.4 \pm 3.89$ & $109.6 \pm 2.22$ & $3.644 \pm 0.11$ & $18.84 \pm 2.12$ & $349.6 \pm 22.00$ \\
\hline 1.0 & $260.5 \pm 4.04$ & $113.4 \pm 2.21$ & $3.821 \pm 0.11$ & $15.34 \pm 1.41$ & $320.1 \pm 17.90$ \\
\hline P değeri & 0.353 & 0.183 & 0.178 & 0.128 & 0.248 \\
\hline \multicolumn{6}{|c|}{ Misir:Arpa x Enzim } \\
\hline $100: 0 \times 0.0$ & $244.0 \pm 8.80$ & $98.9 \pm 3.73$ & $3.168 \pm 0.20$ & $16.63 \pm 0.98^{b}$ & $374.3 \pm 17.98$ \\
\hline $100: 0 \times 1.0$ & $259.6 \pm 8.95$ & $109.0 \pm 6.03$ & $3.443 \pm 0.25$ & $14.09 \pm 1.03^{b}$ & $321.1 \pm 39.79$ \\
\hline $75: 25 \times 0.0$ & $263.8 \pm 6.77$ & $117.1 \pm 2.70$ & $4.053 \pm 0.19$ & $28.14 \pm 4.96^{\mathrm{a}}$ & $446.0 \pm 45.54$ \\
\hline $75: 25 \times 1.0$ & $254.5 \pm 11.38$ & $113.7 \pm 5.22$ & $3.745 \pm 0.22$ & $13.47 \pm 0.74^{\mathrm{b}}$ & $326.0 \pm 42.84$ \\
\hline $50: 50 \times 0.0$ & $254.3 \pm 6.04$ & $110.2 \pm 2.47$ & $3.555 \pm 0.09$ & $13.06 \pm 2.16^{b}$ & $277.7 \pm 17.43$ \\
\hline $50: 50 \times 1.0$ & $253.6 \pm 4.32$ & $112.5 \pm 3.78$ & $3.935 \pm 0.15$ & $14.21 \pm 1.84^{b}$ & $294.5 \pm 20.89$ \\
\hline $0: 100 \times 0.0$ & $259.3 \pm 8.37$ & $112.3 \pm 3.43$ & $3.800 \pm 0.14$ & $17.56 \pm 4.15^{b}$ & $300.6 \pm 34.01$ \\
\hline $0: 100 \times 1.0$ & $274.1 \pm 2.77$ & $118.4 \pm 2.06$ & $4.163 \pm 0.16$ & $19.60 \pm 5.14^{\mathrm{ab}}$ & $339.0 \pm 46.98$ \\
\hline P değeri & 0.302 & 0.378 & 0.209 & 0.050 & 0.129 \\
\hline
\end{tabular}

A, B; Aynı sütunda farklı harfler ile gösterilen ortalamalar arasındaki farklılık istatistiki olarak önemlidir $(\mathrm{P}<0.01)$

a, b; Aynı sütunda farklı harfler ile gösterilen ortalamalar arasındaki farklılık istatistiki olarak önemlidir $(\mathrm{P}<0.05)$

Ana faktör olarak rasyona enzim ilavesinin kemik mineral seviyelerine etkisi olmamıştır $(\mathrm{P}>0.05)$. Ana faktör olarak mısır:arpa oranının kemik kalsiyum, manganez ve çinko seviyelerine etkisi önemsiz olurken ( $\mathrm{P}>0.05)$, kemik fosfor $(\mathrm{P}<0.05)$ ve magnezyum $(\mathrm{P}<0.01)$ seviyelerine etkisi önemli olmuştur. Rasyonda misır yerine arpa kullanımı ile kemik fosfor ve magnezyum seviyeleri artmış, ancak kontrol (100:0) grubu ile karşılaştırıldığında bu artış sadece 75:25 ve 0:100 misır arpa oranlarında istatistiksel olarak önemli olmuştur. Misır:arpa oranı ve enzim ilavesinin oluşturduğu interaksiyonlarından kemik kalsiyum, fosfor, magnezyum ve çinko seviyeleri etkilemezken $(\mathrm{P}>0.05)$, kemik manganez seviyesi önemli derecede etkilenmiştir $(\mathrm{P}<0.05)$. En yüksek kemik manganez seviyesi 75:25x0.0 grubunda elde edilmiş olup bu grup ile $0: 100 \times 1.0$ grubu hariç diğer interaksiyon 
grupları ile arasındaki farklılık önemli olmuştur.

Beta-glukan ve ksilan gibi suda çözünebilen NOP'lar bağırsak viskoziteni arttırarak tavuklarda minerallerin kullanımını olumsuz etkilemektedir (Van der Klis vd., 1993; Kiarie vd., 2014). Ancak mevcut çalışmada arpa kullanımı ile serum ve kemik mineral içeriğinde iyileşme olduğu görülmektedir. Leeson ve Summer (2005) arpanın misirdan daha zengin mineral madde içeriğine sahip olduğunu belirtmektedir. Dolayısıyla rasyonda arpa kullanımı ile serum kalsiyum ve magnezyum ile kemik fosfor ve magnezyum seviyelerinin önemli derecede diğer minerallerin ise rakamsal artmasının muhtemel sebebi arpanın mısıra göre zengin mineral içeriği olabilir. Aynı zamanda bıldırcınlar ile tavukların sindirim fizyolojisi farklılığı da etkili olmuş olabilir. Rasyonda mısır yerine buğday kullanılan rasyonlara enzim (selülaz, glukanaz ve ksilanaz) ilavesinin kan mineral içeriğini etkilemediğini bildirilmektedir (Pan vd., 1998; Silversides vd., 2006). Bu sonuçlar mevcut çalışma ile kısmen benzerlik göstermektedir.

\section{SONUÇ VE ÖNERILER}

Denemeden elde edilen veriler 1şı̆̆ında yumurtlayan bildırcın rasyonlarında arpanın mısır yerine \%100 oranında diğer bir değişle rasyonda \%58 seviyesinde enzim ilaveli olarak arpa kullanılabileceği, ancak yumurta sar1 renginde açılmanın önlenmesi için mutlaka doğal bir renklendiricinin kullanılması gerektiği söylenebilir.

\section{AÇIKLAMA}

Çalışmanın yürütülmesi ve sonuçların yazılması esnasında araştırma ve yayın etiğine uyulmuştur. Herhangi bir "Çıkar Çatışması" bulunmamaktadır. Makalede yazarlar eşit oranda katkı sağlamıştır.

\section{KAYNAKLAR}

Alagawany, M., Elnesr, S.S. ve Farag, M., 2018, The role of exogenous enzymes in promoting growth and improving nutrient digestibility in poultry. Iranian Journal of Veterinary Research, 19 (3), 157-164.

Bedford, M.R. ve Classen, H.L., 1992, Reduction of intestinal viscosity through manipulation of dietary rye and pentosanase concentration is effected through changes in the carbohydrate composition of the intestinal aqueous phase and results in improved growth rate and food conversion efficiency of broiler chicks. The Journal of Nutrition, 122 (3), 560-569.

Duncan, D.B., 1955, Multiple range and multiple F tests, Biometrics, 11(1), 1-42.

Hamilton, R.M.G. ve Proudfoot, F.G., 1993, Effects of dietary barley level on the performance of leghorn hens. Canadian Journal of Animal Science, 73 (3), 625634.

Hebert, K., Tactacan, G.B., Dickson, T.M., Guenter, W. ve House, J.D., 2011, The effect of cereal type and exogenous enzyme use on total folate content of eggs from laying hens consuming diets supplemented with folic acid. Journal Applied Poultry Research, 20 (3), 303-312.

Hetland, H., Choct, M. ve Svihus, B., 2004, Role of insoluble non-starch polysaccharides in 
poultry nutrition. World's Poultry Science Journal, 60 (4), 415-422.

Jamroz, D., Skorupinska, J., Orda, J., Wiliczkiewicz, A. ve Klünter, A.M., 2001, Use of wheat, barley or triticale in feed for laying hens supplemented with carbohydrases derived from Trichoderma longibrachiatum. Journal of Applied Animal Research, 19 (1), 107-116.

Jeroch, H. ve Danicke, S., 1995, Barley in poultry feeding: a review. World's Poultry Science Journal, 51 (3), 271-291.

Kiarie, E., Romero, L.F. ve Ravindran, V., 2014, Growth performance, nutrient utilization, and digesta characteristics in broiler chickens fed corn or wheat diets without or with supplemental xylanase. Poultry Science, 93 (5), 1186-1196.

Lazaro, R., Garcia, M., Aranibar, M. ve Mateos, G., 2003, Effect of enzyme addition to wheat-, barley-and rye-based diets on nutrient digestibility and performance of laying hens. British Poultry Science, 44 (2), 256-265.

Leeson, S. ve Summers, J.D., 2005, Commercial poultry nutrition. 3rd ed. Ontario, Canada, University Books.

Mathlouthi, N., Mohamed, M. ve Larbier, M., 2003, Effect of enzyme preparation containing xylanase and ß-glucanase on performance of laying hens fed wheat/ barley-or maize/soybean meal-based diets. British Poultry Science, 44 (1), 60-66.

Minitab, I., 2000, MINITAB statistical software, Minitab Release, 13, 0.

Mohammed, H., Toson, M., Hassanien, H., Soliman, M. ve El-Nagar, S.H., 2010,
Effect of barley replacement and enzyme supplementation on performance and egg quality of laying hens. Egyptian Poultry Science, 30 (3),731-745.

NRC, 1994. Nutrient requirements of poultry, National Academies Press.

Olgun, O. ve Y1ld1z, A.Ö., 2017, Effects of dietary supplementation of inorganic, organic or nano zinc forms on performance eggshell quality and bone characteristics in laying hens. Annals of Animal Science, 17 (2), 463-476.

Pan, C.F., Igbasen, F.A., Guenter, W. ve Marquardt, R.R., 1998, The effects of enzyme and inorganic phosphorus supplements in wheat- and rye-based diets on laying hen performance, energy, and phosphorus availability. Poultry Science, 77 (1), 83-89.

Perez-Bonilla, A., Frikha, M., Mirzaie, S., Garcia, J. ve Mateos, G., 2011, Effects of the main cereal and type of fat of the diet on productive performance and egg quality of brown-egg laying hens from 22 to 54 weeks of age. Poultry Science, 90 (12), 2801-2810

Silversides, F.G., Scott, T.A., Korver, D.R., Afsharmanesh, M. ve Hruby, M., 2006, A study on the interaction of xylanase and phytase enzymes in wheat-based diets fed to commercial white and brown egg laying hens. Poultry Science, 85 (2), 297-305.

Skujins, S., 1998, Handbook for ICP-AES (Varian-Vista). A short guide to Vista Series ICP-AES Operation, version 1.0. Varian Int. AG, Zug, Switzerland.

Svihus, B., Uhlen, A.K. ve Harstad, O.M., 
2005, Effect of starch granule structure, associated components and processing on nutritive value of cereal starch: A review. Animal Feed Science and Technology, 122 (3-4), 303-320.

Van der Klis, J.D., Verstegen, M.W.A ve Van Voorst, A., 1993, Effect of a soluble polysaccharide (carboxy methyl cellulose) on the absorption of minerals from the gastrointestinal tract of broilers. British Poultry Science, 34 (5), 985-997.

Yörük, M.A. ve Bolat, D., 2003, Arpaya dayalı yumurta tavuğu rasyonlarına farklı enzim katkılarının çeşitli verim özelliklerine etkisi. Turkish Journal of Veterinary and Animal Science, 27 (4), 797-804. 